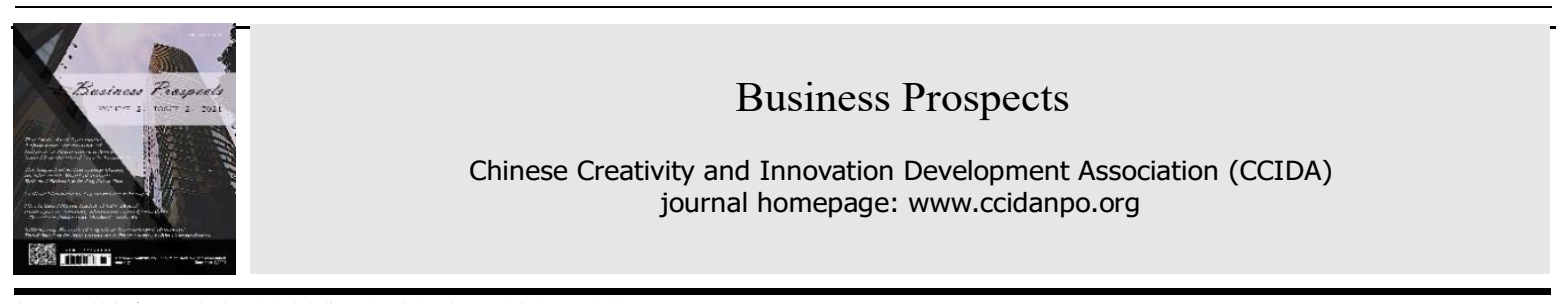

https://doi.org/10.52288/bp.27089851.2021.12.01

\title{
The Impact of Relationship Quality on Electronic Word- of-mouth Referral Behavior in Big Data Era
}

\author{
Jing Wang ${ }^{1, *}$ and Yi-Jie Guo ${ }^{2}$ \\ ${ }^{1}$ Associate Professor of School of International Business, Xiamen University Tan Kah Kee College \\ ${ }^{2}$ School of International Business, Xiamen University Tan Kah Kee College \\ *Correspondence: wangyiyang419@163.com
}

Received: 2021.08.05; Accepted: 2021.10.30; Published: 2021.12.01

\begin{abstract}
Consumer through their referral behavior could be an effective mechanism for marketers in promoting their products in today's big data era. In order to explore the ways that the electronic word-ofmouth referral (e-WOM) comprehensively and effectively influence on the film market in the current media ecological environment in China, this research selects Douban, an outstanding representative of China's online film evaluation platform as the research object and combines the related theories of relationship quality and e-WOM referral behavior to investigate the significant positive influence of the four dimensions of relationship quality (satisfaction, credibility, affection and commitment) on e-WOM referral behavior.
\end{abstract}

Keywords: Relationship Quality; E-WOM Referral Behavior; Douban Platform; Big Data Era

\section{Introduction}

With the rapid development of information technology and the Internet, electronic word of mouth (eWOM) has an increasing impact on consumers' behavior. People can not only obtain commodity information and product usage experience more quickly and efficiently, but have opportunities to share advice and knowledge about specific goods or services with the world (Huang, 2016). At the same time, the integrated development of the media market also promotes the cross-platform communication of e-WOM. With the update and development of information technology, particularly the prosperity of mobile Internet and social media, the traditional way of information sharing for products and services in interpersonal communication has been increasingly replaced by the e-WOM (Chen et al., 2021). It is worth mentioning that cultural products belong to the concept category of consumer goods, so e-WOM has a multi-level impact on experiential media products such as books and films.

Film, as an experiential media product, has both commonness and uniqueness with other cultural products (Huang, 2016). Similar to reading, the symbolic meaning of movies mainly depends on the audience's personal understanding ability. Just like TV, the communication space for audiences is fixed, and there is lack of an interaction between audiences and TV programs, which means that the spread of film WOM also has its particularity. When an audience leaves the closed cinema, it is only a new round begin of WOM. In addition to face-to-face communication, film WOM communication can only rely on other media channels. These WOM effects ultimately lead to the decision of those potential movie consumers to go to the cinema or not, and the results of these decisions are the basis for the next round of WOM, until a film fades from public view.

For several decades, WOM has expressed a simplistic conceptualization focusing especially on favorableness of communication (Chan and Ip, 2011). Another shortcoming of the WOM research during the first decades was that it focused more on the WOM receiver and less on the WOM sender (Liu et al., 2017). Xu et al. (2019) argued that WOM has greatly influenced the choice of products and put less emphasis on the role of the sender of communication who plays a special role in promoting the organization, and there are few researches integrating relationship-quality factors into studies of e-WOM.

While under the influence of social media, a strong relationship has been established between customers and enterprises. In this situation, relationship quality becomes the core concept to measure the relationship 
between consumers and enterprises. At present, academic researches on relationship quality and customer behavior mainly focus on the influence of customer behavior intention, citizenship behavior and WOM behavior. Firstly, from the perspective of customers, their satisfaction, credibility and commitment to the enterprise have an impact on their positive behavior intention (Zhang et al., 2020); Secondly, from an enterprise perspective, a commitment to a customer or to a service organization affects specific aspects of customer citizenship behavior; Lastly, the object of the above researches is aimed at ordinary customers, and there is neither clear and effective segmentation dimension of relationship quality nor in-depth analysis of the impact of segmentation dimension on e-WOM referral. Therefore, this paper takes online film evaluation platform "Douban" as the research object and innovatively combines relationship quality from four dimensions of commitment, satisfaction, affection and credibility to further explore the influencing factors of relationship quality on e-WOM referral behavior of films in big data era.

\section{Literature Reference and Research Hypothesis}

\subsection{Concepts and Dimensions of Relationship Quality}

Initially, the concept of relationship quality is well defined in the field of marketing, which has been generally recognized as interactions between companies and clients (Crosby et al., 1990). After the year 2000, an abundant quantity of relationship quality studies has sprung up, and research objects extended to enterprises and the rest of the pack (Holmlund, 2001). At present, many studies believe that relationship quality is the index of cognition and evaluation of intimacy, credibility and satisfaction between those two parties (Chumg and Huang, 2021; Li et al., 2019; Lu et al., 2018), and it can reflect both parties in the relationship are confident that they can contact each other in the long run (Pang, 2021).

For several years, relationship quality has been treated as an indicator system which depend on various numbers of variables (Crosby et al., 1990; Pang, 2021), and most of the studies mainly focused on evaluating credit levels in social networks, which includes three dimensions of credibility, satisfaction and commitment (Ding and Wei, 2020; Birce, 2020; Ke et al., 2019). More recently, studies of social relationship on the networking sides shift the measurement emphasis away from rational motivation into emotional motivation (Zhao and Zhang, 2020; Wu, 2020), and develop the GRX relational scale of affection and credibility (Yen $e t$ al., 2017). Based on a comprehensive review of classical and recent studies on relationship quality, this article selects 23 most representative literatures to analyze the dimensions of relationship quality.

Table 1. Dimension of relationship quality.

\begin{tabular}{|c|c|c|c|c|c|c|}
\hline & \multirow{2}{*}{ Author } & \multirow{2}{*}{ Year } & \multicolumn{4}{|c|}{ Dimension } \\
\hline & & & Satisfaction & Credibility & Commitment & Affection \\
\hline \multirow{18}{*}{$\begin{array}{c}\text { Classic } \\
\text { References }\end{array}$} & Crosby et al. & 1990 & $\diamond$ & $\diamond$ & & \\
\hline & Holmlund & 2001 & $\diamond$ & & $\bullet$ & \\
\hline & Homburg et al. & 2014 & & $\diamond$ & & $\diamond$ \\
\hline & Hsu \& Lin & 2016 & $\diamond$ & $\diamond$ & & \\
\hline & Yen et al. & 2017 & $\diamond$ & $\diamond$ & & $\diamond$ \\
\hline & Zhang \& Hartley & 2018 & $\diamond$ & $\diamond$ & & $\diamond$ \\
\hline & Lu et al. & 2018 & $\diamond$ & & $\diamond$ & $\diamond$ \\
\hline & Li et al. & 2019 & $\diamond$ & $\diamond$ & & \\
\hline & Pai et al. & 2019 & $\diamond$ & $\diamond$ & & \\
\hline & Ke et al. & 2019 & $\diamond$ & $\diamond$ & $\diamond$ & \\
\hline & Zhang et al. & 2020 & $\diamond$ & $\diamond$ & $\diamond$ & $\diamond$ \\
\hline & Ding \& Wei & 2020 & $\diamond$ & $\diamond$ & $\diamond$ & \\
\hline & Birce & 2020 & $\diamond$ & $\diamond$ & & $\diamond$ \\
\hline & Zhao \& Zhang & 2020 & $\diamond$ & & & $\diamond$ \\
\hline & $\mathrm{Wu}$ & 2020 & $\diamond$ & $\diamond$ & & $\diamond$ \\
\hline & Chumg \& Huang & 2021 & $\diamond$ & $\diamond$ & & \\
\hline & Pang & 2021 & $\diamond$ & $\diamond$ & $\diamond$ & \\
\hline & Chen et al. & 2021 & 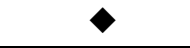 & 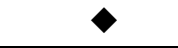 & $\diamond$ & \\
\hline
\end{tabular}




\subsection{E-WOM Referral and Relationship Quality}

Philip Kotler has defined e-WOM behavior in the 21st century as a non-commercial communication behavior, in terms of product, brand, or organization. Traditionally, word-of-mouth (WOM) has been conceptualized as dynamic and on-going information transmitted via person-to-person direct interaction regarding the ownership, impressions, or recommendations of specified products, services, and sellers (Chan and Ip, 2011; Liu et al., 2017; Xu et al., 2019). With the arrival of the Internet age, clients were able to spread and receive information related to products on the Internet, which led to the birth of e-WOM referral acts (Pang, 2021). The concept e-WOM includes any dynamic and on-going evaluations made by those potential, real or previous consumers about products or sellers (Ding and Wei, 2020), which are available to amounts of individuals and organizations through the Internet.

Essentially, relationship quality is a kind of relationship interaction, which is the expression of direct perception as an exchange of relationships (You et al, 2021). Furthermore, exchange behavior is actually a kind of interactive act, in other words, exchange occurs in most interactions, and interaction is always based on the disclosure of information, and e-WOM is not only a relationship exchange but an interaction behavior which takes information as carrier. In the following article, the association between relationship quality and e-WOM will be discussed in detail in the big data era.

Haxhialushi and Panajoti (2018) demonstrated that other sources of information in the web have lesser credibility and empathy for clients than e-WOM, while e-WOM actually has a strong impact on customer behavior and attitude. Pai et al. (2019) have studied on the e-WOM referral behavior and verified that customers credibility has a positive impact on their willingness to submit positive ratings and generate e-WOM; Lu et al. (2018) argued that companies' commitment affects e-WOM referral acts and helps generate positive WOM engagement. Similarity, satisfaction was also clearly identified as a determinant clients' e-WOM communication (Chen et al., 2021; Hsu and Lin, 2016). A lot of researches show that individuals with a high level of affective satisfaction would exert great influence on e-WOM acts. Zhang and Hartley (2018) revealed that affection has a positive effect on business relationships, while this human sympathy would cause greater satisfaction. Thus, this article speculate that Credibility, Commitment, Satisfaction and Affection may have a positively impact on e-WOM referral behaviors.

This research takes Douban (evaluation and rating behavior of film) as an example to explore how the relationship quality motivates consumers to articulate themselves on the Internet from Chinese perspective. In addition, this research defines the previous three dimensions of relationship quality (satisfaction, credibility, commitment) as the functional dimensions, and regarded 'affection' as the affective dimensions, and then take these referred factors as the independent variable, while e-WOM as the dependent variable.

Given the above-mentioned findings, this research has formulated the hypotheses concerning the relationship between relationship quality and e-WOM as follows:

H1: Satisfaction is positively related to film e-WOM referral behavior

$\mathrm{H} 2$ : Credibility is positively related to film e-WOM referral behavior

H3: Affection is positively related to film e-WOM referral behavior

$\mathrm{H} 4$ : Commitment is positively related to film e-WOM referral behavior

\section{Research Methods and Data Analysis}

\subsection{Questionnaire Design and Investigation Method}

The questionnaire uses a 5-level Likert scale, which shows the change of attitude from 1 to 5 . According to the four dimensions of relationship quality finally selected in this research: satisfaction credibility, affection and commitment, the survey questionnaire was designed.

This questionnaire is distributed online, and 421 questionnaires are collected from different regions, occupations and generations. Due to the design of the skipping questions of the questionnaire, there are 20 respondents who have never used Douban platform, so the final number of valid questionnaires is 401 . SPSS25.0 software is used to make an empirical analysis of the specific data collected by the questionnaire.

\subsection{Descriptive Statistical Analysis of Questionnaires}

According to the survey data, the sample of this study shows that, in terms of gender, male interviewees accounted for $43.3 \%$ and female interviewees $56.7 \%$. In terms of age, the proportion of the generation after 00 's 
was $39.3 \%$, and the proportion the generation after 90's was 39.5\%. The age of samples showed a younger trend. In the distribution of education level, the proportion of undergraduate was the highest, accounting for $62.9 \%$, followed by the proportion of junior college was $20.5 \%$. In terms of occupation, $64 \%$ are students and $14 \%$ are employees of enterprises. In terms of the cities where they are located, second-tier cities and above account for $89.1 \%$.

Table 2. Descriptive information for subjects $(\mathrm{N}=421)$.

\begin{tabular}{|c|c|c|c|}
\hline Variables & Category & Frequency & Percentage $(\%)$ \\
\hline \multirow[t]{2}{*}{ Gender } & Male & 182 & 43.3 \\
\hline & Female & 238 & 56.7 \\
\hline \multirow{4}{*}{ Generation } & After 00's & 165 & 39.3 \\
\hline & After 90's & 166 & 39.5 \\
\hline & After 80's & 51 & 12.1 \\
\hline & After 70's and above & 38 & 9 \\
\hline \multirow{4}{*}{$\begin{array}{c}\text { Education } \\
\text { background }\end{array}$} & High school or below & 55 & 13.1 \\
\hline & Junior college & 86 & 20.5 \\
\hline & Undergraduate & 264 & 62.9 \\
\hline & Graduate & 15 & 3.6 \\
\hline \multirow{8}{*}{ Occupation } & Internal student & 269 & 64 \\
\hline & Enterprise staff & 59 & 14 \\
\hline & Civil servants & 11 & 2.6 \\
\hline & Public sector & 16 & 3.8 \\
\hline & Freelancer & 23 & 5.5 \\
\hline & Housewife & 21 & 5 \\
\hline & Private business & 15 & 3.6 \\
\hline & Other & 6 & 1.4 \\
\hline \multirow{6}{*}{ Region } & First-tier cities & 76 & 18.1 \\
\hline & New first-tier cities & 54 & 12.9 \\
\hline & Second-tier cities & 244 & 58.1 \\
\hline & Third-tier cities & 23 & 5.5 \\
\hline & Fourth-tier cities & 10 & 2.4 \\
\hline & Tier 5 and below cities & 13 & 3.1 \\
\hline
\end{tabular}

\subsection{Reliability Analysis of Questionnaires}

Reliability is assessed using Cronbach's $\alpha$. All $\alpha$ values are greater than 0.7 (e-WOM $=0.859$, satisfaction: 0.868 , credibility $=0.880$, affection $=0.859$, commitment $=0.858)$, and the reliability is good, which can be accepted as the questionnaire survey. The fruit has high stability and can be used.

Table 3. Reliability analysis of the measurement model( $\mathrm{N}=401)$.

\begin{tabular}{ccc}
\hline Variables & Cronbach's Alpha & N of items \\
\hline Overall questionnaire & 0.968 & 15 \\
E-WOM Referral & 0.859 & 3 \\
Satisfaction & 0.868 & 3 \\
Credibility & 0.880 & 3 \\
Affection & 0.859 & 3 \\
Commitment & 0.858 & 3 \\
\hline
\end{tabular}




\subsection{Validity of Questionnaires}

In this study, KMO and Bartlett tests are carried out on the 5 variables respectively, so as to test whether the results are suitable for factor analysis. The KMO value is greater than 0.7 and the chi-square value of Bartlett's spherical test reached a significant level, indicating that the structure validity of the questionnaire is good.

Table 4. Validity test of the measurement model $(\mathrm{N}=401)$.

\begin{tabular}{ccc}
\hline & KMO \& Bartlett's test & \\
\hline $\begin{array}{c}\text { KMO measure of sampling } \\
\text { adequacy }\end{array}$ & & 0.983 \\
\hline $\begin{array}{c}\text { Bartlett's test of sphericity } \\
\text { Approx. Chi square }\end{array}$ & $\begin{array}{c}\text { Approximate } \\
\text { Chi-Square }\end{array}$ & $5,334.922$ \\
\cline { 2 - 3 } & $\begin{array}{r}\mathrm{df} \\
\text { sig. }\end{array}$ & 105 \\
\hline
\end{tabular}

Extraction method: principal component analysis

Table 5. Total variance explained ( $\mathrm{N}=401)$.

\begin{tabular}{|c|c|c|c|c|c|c|c|c|c|}
\hline \multirow[t]{2}{*}{ Component } & \multicolumn{3}{|c|}{ Initial eigenvalues } & \multicolumn{3}{|c|}{$\begin{array}{c}\text { Extraction sum of squared } \\
\text { loadings }\end{array}$} & \multicolumn{3}{|c|}{$\begin{array}{c}\text { Rotation sum of squared } \\
\text { loadings }\end{array}$} \\
\hline & Total & $\begin{array}{c}\% \text { of } \\
\text { variance }\end{array}$ & $\begin{array}{c}\text { Cumulative } \\
\%\end{array}$ & Total $\%$ & $\begin{array}{c}\% \text { of } \\
\text { variance }\end{array}$ & $\begin{array}{c}\text { Cumulative } \\
\%\end{array}$ & Total $\%$ & $\begin{array}{c}\% \text { of } \\
\text { variance }\end{array}$ & $\begin{array}{c}\text { Cumulative } \\
\%\end{array}$ \\
\hline 1 & 10.41 & 69.399 & 69.399 & 10.410 & 69.399 & 69.399 & 2.760 & 18.403 & 18.403 \\
\hline 2 & 0.467 & 3.116 & 72.515 & 0.467 & 3.116 & 72.515 & 2.752 & 18.349 & 36.751 \\
\hline 3 & 0.427 & 2.845 & 75.360 & 0.427 & 2.845 & 75.360 & 2.356 & 15.707 & 52.458 \\
\hline 4 & 0.387 & 2.583 & 77.943 & 0.387 & 2.583 & 77.943 & 2.311 & 15.410 & 67.868 \\
\hline 5 & 0.363 & 2.42 & 80.363 & 0.363 & 2.420 & 80.363 & 1.874 & 12.495 & 80.363 \\
\hline 6 & 0.354 & 2.358 & 82.720 & & & & & & \\
\hline 7 & 0.347 & 2.315 & 85.035 & & & & & & \\
\hline 8 & 0.331 & 2.204 & 87.239 & & & & & & \\
\hline 9 & 0.326 & 2.176 & 89.415 & & & & & & \\
\hline 10 & 0.312 & 2.083 & 91.498 & & & & & & \\
\hline 11 & 0.288 & 1.921 & 93.420 & & & & & & \\
\hline 12 & 0.266 & 1.776 & 95.196 & & & & & & \\
\hline 13 & 0.256 & 1.709 & 96.905 & & & & & & \\
\hline 14 & 0.243 & 1.621 & 98.526 & & & & & & \\
\hline 15 & 0.221 & 1.474 & 100.00 & & & & & & \\
\hline
\end{tabular}

Extraction method: principal component analysis

\subsection{Correlation Analysis of Questionnaires}

This study adopts correlation analysis method to study the correlation between four dimensions of relationship quality and word-of-mouth recommendation behavior.

The correlation coefficients for the study variables reveal that generation is significantly positively correlated with credibility $(r=0.223, \mathrm{P}<0.01)$; satisfaction is significantly positively correlated with e-WOM referral $(r=0.860, P<0.01)$; credibility is significantly positively correlated with e-WOM referral $(r=0.848$, $\mathrm{P}<0.01)$; affection is significantly positively correlated with e-WOM referral $(\mathrm{r}=0.854, \mathrm{P}<0.01)$ and commitment is significantly positively correlated with e-WOM referral $(r=0.854, \mathrm{P}<0.01)$. 
Table 6. Correlation analysis of each variable.

\begin{tabular}{|c|c|c|c|c|c|c|c|c|c|c|c|c|}
\hline & Mean & Std & Gender & Generation & Education & Occupation & Region & Satisfaction & Credibility & Affection & Commitment & $\begin{array}{c}\text { Buying } \\
\text { Intention }\end{array}$ \\
\hline Gender & 1.56 & 0.497 & 1 & & & & & & & & & \\
\hline Generation & 1.93 & 0.941 & -.800 & 1 & & & & & & & & \\
\hline Education & 2.56 & 0.770 & $.105^{*}$ & $-.338^{* *}$ & 1 & & & & & & & \\
\hline Occupation & 2.14 & 1.902 & .260 & $.574^{* *}$ & $-.300^{* *}$ & 1 & & & & & & \\
\hline Region & 2.69 & 1.089 & -.001 & -.069 & -.096 & -.022 & 1 & & & & & \\
\hline Satisfaction & 11.43 & 2.916 & $-.305^{* *}$ & $.216^{* *}$ & -.098 & -.076 & -.041 & 1 & & & & \\
\hline Credibility & 11.50 & 2.989 & $-.302^{* *}$ & $.223^{* * *}$ & -.088 & -.050 & -.007 & $.854^{* * *}$ & 1 & & & \\
\hline Affection & 11.45 & 2.991 & $-.296^{* *}$ & $.232^{* *}$ & $-.131^{* *}$ & -.031 & -.014 & $.845^{* *}$ & $.844^{* *}$ & 1 & & \\
\hline Commitment & 11.41 & 2.863 & $-259^{* *}$ & $.204^{* *}$ & -.083 & $-.104^{*}$ & -.020 & $.850^{* *}$ & $.849^{* *}$ & $.856^{*}$ & 1 & \\
\hline $\begin{array}{c}\text { Buying } \\
\text { Intention }\end{array}$ & 11.37 & 2.858 & $-.273^{* *}$ & $-.248^{* *}$ & $-.108^{* *}$ & -.045 & -.047 & $.860^{* *}$ & $.848^{* *}$ & $.854^{* *}$ & $.854^{* *}$ & 1 \\
\hline
\end{tabular}

${ }^{*}$ At the 0.05 level (double-tailed), the correlation was significant.

${ }^{* *}$ At the 0.01 level (double-tailed), the correlation was significant.

\subsection{Regression Analysis of Questionnaires}

This study uses linear regression analysis to test whether the four dimensions of relationship quality have significant causal relationship. Among them, customers' purchase intention is the dependent variable, and the four dimensions of relationship quality are the independent variables.

To evaluate the Hypothesis 1-4, the direct impact of the hypothesized model based on standardized regression weights are presented in Table 7 . The results reveal that satisfaction is positively related to film eWOM referral behavior $(0.836, \mathrm{P}<0.001$; credibility is positively related to film e-WOM referral behavior $(0.416, \mathrm{P}<0.001)$; affection are positively related to film e-WOM referral behavior $(0.328, \mathrm{P}<0.001)$ commitment is positively related to film e-WOM referral behavior $(0.226, \mathrm{P}<0.001)$.

Table 7. Regression analysis of each variable $(\mathrm{N}=401)$.

\begin{tabular}{cccccc}
\hline Variables & Model 1 & Model 2 & Model 3 & Model 4 & Model 5 \\
\hline Gender & -0.234 & -0.010 & 0.009 & 0.015 & 0.008 \\
Generation & 0.364 & 0.081 & 0.059 & 0.053 & 0.043 \\
Education & -0.036 & -0.006 & -0.010 & 0.003 & 0.001 \\
Occupation & -0.259 & -0.030 & -0.025 & -0.026 & -0.008 \\
Region & -0.024 & -0.007 & -0.019 & -0.024 & -0.023 \\
Satisfaction & & 0.836 & 0.490 & 0.341 & 0.276 \\
Credibility & & & 0.416 & 0.271 & 0.205 \\
Affection & & & & 0.328 & 0.246 \\
Commitment & & & & & 0.226 \\
\hline $\mathrm{R}^{2}$ & 0.171 & 0.744 & 0.790 & 0.815 & 0.825 \\
Adj. $\mathrm{R}^{2}$ & 0.160 & 0.740 & 0.787 & 0.811 & 0.821 \\
F & 16.225 & 190.693 & 211.248 & 215.331 & 203.729 \\
D-W & & 2.012 & 1.895 & 1.938 & 1.89 \\
\hline
\end{tabular}

\section{Conclusions}

This research is based on the four dimensions of relationship quality (satisfaction, credibility, human hypothesis, affective factors and commitment) to analyze the impact of film e-WOM referral in the current big data media ecological environment in China. The result shows that all four dimensions are positively and significantly related to the film word-of-mouth referral behavior.

In the context of the Internet, most of the traditional marketing channels have been transformed into online media. Similarly, the development of the film industry also needs Internet media. As an outstanding representative of the Douban film review platform, it has built an e-WOM referral ecosystem of films and 
greatly influenced the contemporary film market. It is not difficult to find that the generation of e-WOM referral directly comes from consumers' dependence on the use of the platform, that is, the relationship quality between users and the platform. Thus, quality relationship becomes the key factor in contemporary film market.

\section{References}

1. Birce, D. (2020). The Role of Guanxi on International Business-to-business Relationships: A Systematic Review and Future Directions. The Journal of Business \& Industrial Marketing, 35(7): 1125-1140.

2. Chan, S. L., \& Ip, W. H. (2011). A Dynamic Decision Support System to Predict the Value of Customer for New Product Development. Decision Support Systems, 52(1): 178-188.

3. Chen, X. F., Ma, J. Q., Wei, L., \& Yang, S. Q. (2021). The Role of Perceived Integration in WeChat Usages for Seeking Information and Sharing Comments: A Social Capital Perspective. Information \& Management, 58(1): 1-9.

4. Chumg, H. F., \& Huang, C. J. (2021). Investigating the Relationships Between Cultural Embeddedness, Happiness, and Knowledge Management Practices in an Inter-Organizational Virtual Team. Frontiers in Psychology, 11: 1-14.

5. Crosby, L. A., Evans, K. R., \& Cowles, D. (1990). Relationship Quality in Services Selling: An Interpersonal Influence Perspective. Journal of Marketing, 54(3): 68-81.

6. Ding, Z., \& Wei, H. Q. (2020). Study of the Characteristics of Chinese Guanxi and Its Influence on Business Development. Proceedings of the 6th International Conference on Humanities and Social Science Research (ICHSSR 2020), 435: 1-4.

7. Haxhialushi, R., \& Panajoti, V. H. (2018). How Word of Mouth in Social Media Affects Attitudes Toward Brands. China-USA Business Review, 17(5): 245-255.

8. Holmlund, M. (2001). The D\&D Model-Dimensions and Domains of Relationship Quality Perceptions. Service Industries Journal, 21(3): 13-36.

9. Homburg, C., Bornemann, T., \& Kretzer, M. (2014). Delusive Perception-Antecedents and Consequences of Salespeople's Misperception of Customer Commitment. Journal of the Academy of Marketing Science, 42(2): 137153.

10. Hsu, C. L., \& Lin, J. C. C. (2016). Effect of Perceived Value and Social Influences on Mobile App Stickiness and Inapp Purchase Intention. Technological Forecasting and Social Change, 108(C): 42-53.

11. Huang, K. (2016). The System Analysis of the Online WOM Influence on Films in New Media Era. Contemporary Cinema, 3:194-197.

12. Ke, Y. J., Ling, F. Y. Y., Ning, Y., \& Zhang, Z. (2019). Managing Relationships in Large Public Projects: Comparative Study of China and Singapore. Built Environment Project and Asset Management, 9(3): 348-363.

13. Li, L., Li, G., Feng, X. L., Liu, Z. G., \& Tsai, F. S. (2019). Moderating Effect of Dynamic Environment in the Relationship between Guanxi, Trust, and Repurchase Intention of Agricultural Materials. International Journal of Environmental Research and Public Health, 16(19): 3773.

14. Liu, X., Hu, J., \& Xu, B. (2017). Does e-WOM Matter to Brand Extension? An Examination of the Impact of Online Reviews on Brand Extension Evaluations. Journal of Research in Interactive Marketing, 11(3): 232-245.

15. Lu, H. E., Potter, A., Rodrigues, V. S., \& Walker, H. (2018). Exploring Sustainable Supply Chain Management: A Social Network Perspective. Supply Chain Management, 23(4): 257-277.

16. Pai, C. H., Ko, K. M., \& Santos, T. (2019). A Study of the Effect of Service Recovery on Customer Loyalty Based on Marketing Word of Mouth in Tourism Industry. Revista de Cercetare si Interventie Sociala, 64: 74-84.

17. Pang, H. (2021). Identifying Associations between Mobile Social Media Users' Perceived Values, Attitude, Satisfaction, and e-WOM Engagement: The Moderating Role of Affective Factors. Telematics and Informatics, 59(6). (https://doi.org/10.1016/j.tele.2020.101561)

18. Wu, W. K. (2020). The Impact of Customer-Salesperson Guanxi and Customer Dependence upon Salesperson Influence Effectiveness. Journal of Promotion Management, 26(5): 1-20.

19. Xu, X., Yao, Z. \& Sun, Q. (2019). Social Media Environments Effect on Perceived Interactivity: An Empirical Investigation from WeChat Moments. Online Information Review, 43(2): 239-255.

20. Yen, D. A., Abosag, I., Huang, Y. A., \& Nguyen, B. (2017). Guanxi GRX (Ganqing, Renqing, Xinren) and Conflict Management in Sino-US Business Relationships. Industrial Marketing Management, 66: 103-114.

21. You, Y., He, Y., Chen, Q. M., \& Hu, M. (2021). The Interplay between Brand Relationship Norms and Ease of Sharing on Electronic Word-of-mouth and Willingness to Pay. Information \& Management, 58(2). (https://doi.org/10.1016/ j.im.2020.103410)

22. Zhang, D. P., Qi, X. B., \& Lin, M. F. (2020). The Influence of Innovating Customer's Psychological Ownership and Relationship Quality on Word-of-Mouth Recommendation Behavior. Forecasting, 39(6): 39-46. 
23. Zhang, M., \& Hartley, J. L. (2018). Does Guanxi Influence Product Performance and Customer Loyalty? Journal of Asia Business Studies, 12(3): 233-252.

24. Zhao, H. C., \& Zhang, M. Y. (2020). The Role of Guanxi and Positive Emotions in Predicting Users' Likelihood to Click the Like Button on WeChat. Frontiers in Psychology, 11(1736): 1-10.

(Editor: Xiaoxuan Liu) 